\title{
Dampak Penerapan Fasilitasi Sarana Pascapanen terhadap Kualitas Jagung (Zea mays L.) di Indonesia
}

\author{
Effect of Postharvest Mechanization Facility on Quality of Maize (Zea mays L.) in Indonesia \\ Deasy Fitriati*, Vera Ramashinta, Hastari Kusumawardhani \\ Direktorat Pengolahan dan Pemasaran Hasil Tanaman Pangan, Direktorat Jenderal Tanaman Pangan, \\ Kementerian Pertanian, Jl. Raya Ragunan No. 15, Pasar Minggu, Jakarta Selatan 17550, Indonesia \\ *Penulis korespondensi: Deasy Fitriati, Email: deasyfitri@gmail.com
}

Tanggal submisi: 1 Juni 2020; Tanggal revisi: 21 Agustus 2020 Tanggal penerimaan: 25 Agustus 2020

\begin{abstract}
ABSTRAK
Penelitian yang bertujuan untuk mengevaluasi kualitas jagung setelah penerapan fasilitasi sarana pascapanen dari pemerintah. Kegiatan ini dilaksanakan di sentra produksi jagung di Indonesia pada tahun 2017-2019. Pengumpulan data dilakukan dengan metode survei dan sampel dipilih berdasarkan metode stratified random sampling. Hasil penelitian menunjukkan bahwa mutu jagung di Indonesia berfluktuatif. Kandungan aflatoksin pada sampel 0,05 $\mu \mathrm{g} / \mathrm{kg}$ sampai $976,25 \mu \mathrm{g} / \mathrm{kg}$ dan kandungan biji pecah serta rusak 0 sampai $34,40 \%$. Kontaminasi aflatoksin yang berada di atas $150 \mu \mathrm{g} / \mathrm{kg}$ (batas maksimum pada SNI) sebanyak 5\% dari total sampel. Di beberapa provinsi, kandungan aflatoksin, kadar air, biji rusak dan biji pecah tidak masuk dalam persyaratan mutu jagung yang terdapat pada SNI. Peningkatan mutu jagung belum menjadi prioritas bagi petani dan pedagang. Karena belum adanya insentif terhadap proses pascapanen yang menjaga mutu hasil produksi. Fasilitasi sarana yang berupa mesin pascapanen diberikan pemerintah kepada petani masih sebatas untuk mengurangi losses. Namun, kualitatif losses belum sesuai dengan target yang diinginkan. Hasil penelitian ini dapat digunakan oleh pembuat kebijakan untuk keberhasilan pelaksanaan program di masa yang akan datang.
\end{abstract}

Kata kunci: Aflaktoksin; sarana pascapanen; kualitas jagung

\begin{abstract}
This study aimed to evaluate the quality of maize due to postharvest mechanization. The activities were conducted in Indonesia's maize central production in 2017 to 2019. A survey method with stratified random sampling was applied in data collection. The study revealed that the quality of maize production in Indonesia was fluctuating. The level of aflatoxins in all the samples was between 0.05 and $976.25 \mu \mathrm{g} / \mathrm{kg}$ and there was $0-34.4 \%$ split and broken seeds. The aflatoxin contamination of which the value was above $150 \mu \mathrm{g} / \mathrm{kg}$ (the maximum tolerable level in SNI) reached $5 \%$ of the total samples. In some provinces, the aflatoxin content, moisture content, split seeds and broken seeds were not included as maize quality requirements in Indonesia National Standard (SNI). Farmers and traders had not yet prioritized how to increase maize quality because no incentive was given when they implemented postharvest activities to maintain maize quality. The postharvest machinery given by the government only aimed to reduce losses, but not qualitative losses. The result of this study could be used by decision makers as a consideration in designing programs to achieve better results in the future.
\end{abstract}

Keywords: Aflatoxin; postharvest mechanization; maize quality 


\section{PENDAHULUAN}

Populasi penduduk di Indonesia mencapai 265 juta jiwa dengan pertumbuhan rata-rata 1,19\% (BPS, 2019). Sehingga, produk pertanian harus ditingkatkan untuk mengakomodir peningkatan populasi. Jagung mempunyai potensi yang tinggi dalam pemenuhan kebutuhan pokok di Indonesia dan merupakan tanaman pangan kedua setelah beras walaupun mayoritas penggunaannya sebagai pakan. Stewart dan Roberts (2012) mengindikasikan bahwa konsumsi pangan berupa daging terus meningkat, sehingga kebutuhan jagung sebagai bahan dasar pakan juga akan terus meningkat. Produksi daging ayam petelur dan pedaging di Indonesia mengalami peningkatan yaitu 4,50\% (BPS, 2019). Jagung merupakan sumber energi penting pada unggas dimana 50\%-70\% dari bahan pakannya adalah jagung (Subekti, 2009). Oleh karena itu, keberlangsungan panen dan kualitas jagung pasok sangat dibutuhkan.

Harga pakan sangat tergantung oleh harga beli jagung, karena $70 \%$ dari total biaya produksi pakan digunakan untuk pengadaan jagung. Pada akhirnya, harga jagung akan mempengaruhi harga telur dan ayam potong. Keterbatasan pasokan akan mengakibatkan pelonjakan harga jagung pipilan. Namun demikian tidak semua hasil panen jagung pipilan petani bisa diserap oleh pabrik pakan dikarenakan persyaratan spesifik dari pabrik pakan terutama pada kandungan aflatoksin yang tidak bisa dipenuhi petani. Selain itu, kadar air juga merupakan standar mutu pembelian jagung oleh pabrik pakan karena kadar air akan mempengaruhi kualitas jagung selama penyimpanan (Mitchell, 2004).

Keterbatasan suplai jagung juga mengakibatkan peningkatan impor yang dilakukan oleh pabrik pakan. Namun, harga jagung dalam negeri tidak dapat bersaing dengan harga impor. Harga domestik dapat dilindungi hanya dengan pembatasan impor dan ekspor, sehingga suplai domestik dapat ditingkatkan dan harga domestik akan optimum (Djuric dan Götz, 2016). Peningkatan suplai jagung pipilan juga dapat ditingkatkan melalui pendekatan penurunan kehilangan hasil pada proses pascapanen (losses). Menurut Parfitt dkk. (2010), ketersediaan pangan dapat ditingkatkan dengan penurunan losses dari pada peningkatan produksi. Ada beberapa faktor yang merupakan penyebab utama kehilangan hasil secara kualitatif dan kuantitatif. Faktorfaktor tersebut meliputi penanganan pascapanen jagung yang dilakukan secara tidak tepat, perencanaan transportasi yang tidak layak, skenario yang tidak cocok antara produksi dan kebutuhan, infrastruktur yang tidak memadai, pengiriman yang tidak tepat waktu, dan rantai pasok yang tidak efisien (Maiyar dan Thakkar, 2017).

Kuantitatif losses pada proses pascapanen jagung berkisar antara 5-10\% (Purwadaria, 1988). Penurunan kualitas yang paling utama adalah disebabkan oleh kontaminasi aflatoksin. Aflatoksin merupakan jamur yang memiliki efek beracun dan memberikan dampak negatif pada ekonomi dan perdagangan (Wild dan Gong, 2010), keamanan serta kesehatan hewan dan manusia (Krout-Greenberg dkk., 2013; Zulkifli dan Zakaria, 2017). Aflatoksin dihasilkan oleh Aspergillus flavus and A. parasiticus (Udomkun dkk., 2017). Kemudian, kedua jamur tersebut meracuni pada kurun waktu yang panjang (van Egmond dkk., 2007). Petani dan pedagang umumnya tidak peduli terhadap kontaminasi jagung yang disebabkan oleh aflatoksin (Udomkun dkk., 2018).

Sistem pascapanen yang efektif dapat memastikan hasil panen mencapai konsumen dan memuaskan konsumen dari segi kualitas, volume, dan keamanan (Abass dkk., 2014; Stewart dan Roberts, 2012). PemerintahmelaluiKementerian Pertanianmelaksanakan kegiatan fasilitasi sarana Pascapanen Tanaman Pangan berupa combine harvester, corn sheller, dan vertical dryer kepada kelompok tani. Keberhasilan program tersebut dapat dilihat dari peningkatan produksi atas penurunan kehilangan hasil dan peningkatan kualitas hasil panen. Oleh karena itu, untuk mengetahui dampak dari program fasilitasi tersebut, kegiatan survei terkait dengan kuantitas dan kualitas panen jagung di sentra produsi jagung di Indonesia mutlak untuk dilakukan.

Penelitian ini bertujuan untuk mengetahui kualitas jagung pada tingkat petani dan pedagang di sentra produksi jagung di Indonesia setelah dilakukan fasilitasi peralatan pascapanen oleh Kementerian Pertanian.

\section{METODE PENELITIAN}

Pengumpulan data dilakukan pada Tahun 20172019 di beberapa kabupaten yang pernah menerima bantuan sarana Pascapanen jagung. Data diperoleh dengan metode Stratified Random Sampling di 9 provinsi sentra produksi jagung. Metode tersebut digunakan karena adanya perbedaan jenis dan spesifikasi sarana pascapanen yang difasilitasikan pada setiap lokasi. Pengumpulan data produksi, harga jual/beli, dan aktifitas pascapanen menggunakan seperangkat kuesioner. Sedangkan pengumpulan sampel biji jagung dilakukan secara acak dari setiap wilayah produksi responden.

Sampel uji diperoleh dari 143 responden pada beberapa level rantai pasok yaitu petani, pedagang pengumpul kecil (PPK), pedagang pengumpul besar (PPB), dan eksportir. Sampel jagung pipilan yang diperoleh dianalisis kadar air, aflatoksin B1, biji pecah, dan biji rusak di Laboratorium Pengujian yang telah diakreditasi oleh Komite Akreditasi Nasional (KAN). Analisa kadar air menggunakan oven, aflatoksin B1 dengan HPLC dihubungkan dengan Triple Quadrupole 
dengan detektor Tandom Mask Spectrometry (LC-MS/ MS), dan analisa organoleptik mengacu SNI 4483-2013. Pengujian mutu jagung tersebut dilakukan di beberapa lokasi sesuai dengan wilayah pengambilan sampel jagung.

Parameter pengamatan dilakukan berdasarkan spesifikasi persyaratan mutu jagung pada SNI 3920:2013 dan SNI 4483:2013 yang terdiri dari kandungan aflatoksin, kadar air, butir rusak, dan butir pecah. Butir rusak adalah jagung yang utuh maupun pecah yang mengalami kerusakan karena kerusakan mekanis, biologis, fisik dan enzimatis. Butir pecah adalah jagung yang pecah selama penanganan pascapanen yang mempunyai ukuran sama atau lebih kecil dari 0,60 bagian jagung. Persyaratan mutu jagung yang digunakan sebagai perbandingan adalah persyaratan mutu pada kelas terendah yaitu Mutu IV pada SNI 3920:2013 dan Mutu II pada SNI 4483:2013.

Dalam rangka melengkapi data dan informasi, data sekunder digunakan pada penelitian ini. Data sentra produksi jagung, database sarana pascapanen jagung, lokasi pedagang dan pabrik pakan didapatkan dari Kementerian Pertanian. Database sarana pascapanen jagung yang difasilitasi dari dana APBD (Anggaran Pendapatan dan Belanja Daerah) diperoleh dari Dinas Pertanian Provinsi/Kabupaten/Kota. Data jumlah penduduk, konsumsi daging per kapita disediakan melaluiBiro Pusat Statistik dan beberapa data dukung seperti lokasi pedagang jagung tingkat desa/kecamatan/ kabupaten didapatkan dari perangkat desa dan dinas peternakan wilayah setempat.

\section{HASIL DAN PEMBAHASAN}

Hasil pengujian menunjukan bahwa terdapat 9 provinsi yang dapat memproduksi jagung sesuai dengan kriteria kualitas SNI Jagung (3920:2013) dan SNI Jagung - Bahan pakan ternak (4483:2013). Hasil selengkapnya pengujian mutu jagung tersebut disajikan pada Tabel 1, Tabel 2, dan Tabel 3.

Tabel 3. Mutu jagung di Provinsi Sulawesi Barat tahun 2019

\begin{tabular}{lccc}
\hline \multicolumn{1}{c}{ Parameter } & $\begin{array}{c}\text { Sulawesi } \\
\text { Barat }\end{array}$ & $\begin{array}{c}\text { SNI } \\
\text { 3920:2013 } \\
\text { (Mutu IV) }\end{array}$ & $\begin{array}{c}\text { SNI } \\
\text { (Mutu II) }\end{array}$ \\
\hline $\begin{array}{l}\text { Aflatoxin B1 } \\
(\mu \mathrm{g} / \mathrm{kg})\end{array}$ & $14,5 \pm 19,3$ & 20 & 150 \\
Kadar air $(\%)$ & $9,6 \pm 1,4$ & 17 & 16 \\
Biji pecah (\%) & $2,5 \pm 1,2$ & 3 & 4 \\
Biji Rusak (\%) & $9,5 \pm 3,8$ & 8 & 5 \\
\hline
\end{tabular}

Provinsi Gorontalo, Jawa tengah, Sulawesi Barat, dan Sulawesi Selatan menghasilkan jagung dengan

Tabel 1. Mutu jagung pada beberapa provinsi di Indonesia Tahun 2017

\begin{tabular}{lcccccccc}
\hline \multicolumn{1}{c}{ Parameter } & $\begin{array}{c}\text { Sumatera } \\
\text { Utara }\end{array}$ & Jawa Barat & Jawa Tengah & NTT & Gorontalo & $\begin{array}{c}\text { Sulawesi } \\
\text { Selatan }\end{array}$ & $\begin{array}{c}\text { SNI } \\
\text { (Mutu IV) }\end{array}$ & $\begin{array}{c}\text { SNI } \\
\text { (Mutu II) }\end{array}$ \\
\hline $\begin{array}{l}\text { Aflatoxin B1 } \\
(\mu \text { g/kg) }\end{array}$ & $27,4 \pm 80,0$ & $3,2 \pm 8,4$ & $100,3 \pm 204,9$ & $11,3 \pm 13,9$ & $24,8 \pm 24,0$ & $74,0 \pm 132,5$ & 20 & 150 \\
Kadar air (\%) & $169,0 \pm 9,9$ & $19,6 \pm 5,9$ & $11,4 \pm 2,1$ & $6,7 \pm 1,3$ & $8,7 \pm 1,3$ & $25,9 \pm 12,2$ & 17 & 16 \\
$\begin{array}{l}\text { Biji pecah } \\
(\%)\end{array}$ & $5,3 \pm 10,6$ & $1,5 \pm 4,5$ & $0,9 \pm 1,3$ & $0,6 \pm 0,6$ & $0,6 \pm 0,3$ & $16,2 \pm 14,5$ & 3 & 4 \\
Biji rusak (\%) & $0,9 \pm 1,2$ & $3,7 \pm 4,1$ & $1,0 \pm 0,7$ & $0,3 \pm 0,4$ & $1,2 \pm 0,5$ & $0,1 \pm 0,2$ & 8 & 5 \\
\hline
\end{tabular}

Tabel 2. Mutu jagung pada beberapa provinsi di Indonesia Tahun 2018

\begin{tabular}{lccccccccc}
\hline \multicolumn{1}{c}{ Parameter } & NTB & $\begin{array}{c}\text { Sulawesi } \\
\text { Utara }\end{array}$ & $\begin{array}{c}\text { Sulawesi } \\
\text { Barat }\end{array}$ & $\begin{array}{c}\text { Jawa } \\
\text { Tengah }\end{array}$ & NTT & Gorontalo & $\begin{array}{c}\text { Sulawesi } \\
\text { Selatan }\end{array}$ & $\begin{array}{c}\text { SNI } \\
3920: 2013 \\
\text { (Mutu IV) }\end{array}$ & $\begin{array}{c}4483: 2013 \\
\text { (Mutu II) }\end{array}$ \\
\hline $\begin{array}{l}\text { Aflatoxin B1 } \\
(\mu \text { g/kg) }\end{array}$ & $135,2 \pm 232,3$ & $1,0 \pm 1,9$ & $31,0 \pm 36,2$ & $0,0 \pm 0,0$ & $27,2 \pm 43,1$ & $18,7 \pm 27,9$ & $39,6 \pm 100,6$ & 20 & 150 \\
Kadar air (\%) & $17,1 \pm 7,2$ & $17,5 \pm 3,8$ & $14,5 \pm 0,7$ & $9,0 \pm 2,0$ & $10,7 \pm 1,4$ & $8,5 \pm 1,4$ & $14,6 \pm 5,5$ & 17 & 16 \\
$\begin{array}{l}\text { Biji pecah } \\
(\%)\end{array}$ & $0,7 \pm 1,4$ & $0,5 \pm 0,7$ & $1,5 \pm 0,9$ & $1,2 \pm 1,1$ & $0,9 \pm 1,1$ & $0,5 \pm 0,4$ & $1,2 \pm 1,5$ & 3 & 4 \\
Biji rusak (\%) & $0,5 \pm 0,9$ & $4,3 \pm 4,5$ & $5,9 \pm 3,6$ & $0,9 \pm 1,3$ & $3,8 \pm 2,9$ & $0,6 \pm 0,5$ & $0,7 \pm 0,8$ & 8 & 5 \\
\hline
\end{tabular}


kualitas yang lebih baik dibandingkan pada tahun sebelumnya. Kualitas jagung baik Aflatoxin B1 maupun kadar air pada provinsi Jawa tengah dan Sulawesi Barat sesuai dengan persyaratan mutu SNI 3920:2013 maupun SNI 4483:2013. Provinsi Sulawesi Selatan memproduksi jagung dengan kandungan aflatoksin yang melebihi batas SNI 3920:2013, walaupun jagung tersebut masih sesuai dengan persyaratan SNI 4483:2013 (kelas terendah Mutu II).

Berbeda halnya dengan Provinsi Nusa Tenggara Timur (NTT), jagung yang dihasilkan memiliki kualitas yang semakin menurun dibandingkan dengan tahun sebelumnya, terutama pada kandungan aflatoksin. Namun, jagung pada wilayah ini masih masuk kedalam SNI 4483:2013.

Jagung yang dihasilkan di provinsi Sumatera Utara, Jawa Barat, Sulawesi Utara, dan NTB tidak masuk dalam persyaratan mutu SNI Jagung dan SNI Jagung Bahan pakan ternak. Walaupun demikian, kandungan aflatoksin jagung di 4 provinsi tersebut masih memenuhi kriteria mutu yang dipersyaratkan oleh SNI 4483:2013 (kelas terendah Mutu II).

Persyaratan mutu di pabrik pakan ternak memfokuskan pada mutu kadar air dan aflatoksin. Kadar air jagung yang dibeli oleh pabrik pakan mensyaratkan kurang dari $17 \%$, namun demikian, kadar air yang melebihi persyaratan masih dapat diterima dengan kompensasi harga pembelian jagung dikurangi dengan biaya pengeringan. Data yang diperoleh di beberapa Dinas Pertanian Provinsi juga memuat kualitas jagung di tingkat petani dan pedagang (Tabel 4).

Pada setiap provinsi, kandungan biji pecah dan rusak dari tingkat petani ke tingkat pedagang cenderung meningkat, kecuali pada provinsi Jawa Barat yang mengalami sedikit penurunan. Hal ini dimungkinkan karena aplikasi sarana pascapanen yang tidak sesuai dengan prosedur pengoperasian sehingga berakibat pada penurunan kualitas biji jagung. Proses panen menggunakan combine harvester mensyaratkan jagung tongkolan dengan kadar air tertentu. Tingginya kadar air jagung dapat merusak butir jagung, tongkolan mudah hancur dan terikut kedalam jagung pipilan. Demikian juga halnya dengan pengoperasian corn sheller pada jagung tongkolan kadar air tinggi. Pemanfaatan vertical dryer membutuhkan keahlian dari operator. Penggunaan yang tidak tepat dapat mengakibatkan jagung pipilan kusam bahkan menghitam/terbakar. Cara panen, pengeringan, perontokan, penyimpanan merupakan periode kritis dalam menjaga kualitas jagung pipilan (Pandey dkk., 2013). Penundaan pada waktu panen setelah masak fisiologis akan mengakibatkan peningkatan kehilangan hasil secara kualitatif (Panison dkk., 2016). Menurut GU dkk. (2019), penggunaan perontok mekanik yang tidak tepat dapat merusak dan menurunkan kualitas biji jagung.

Kandungan aflatoksin biji jagung dari petani ke pedagang menunjukan tren yang semakin meningkat. Kandungan aflatoksin di pedagang ditentukan oleh penanganan pascapanen yang dilakukan di tingkat pedagang untuk menjaga kestabilan mutu jagung yang dibeli dari petani atau dari pedagang pada rantai pasok dibawahnya. Proses pengeringan jagung pipilan tidak dilakukan oleh semua pedagang. Pada umumnya, pedagang melakukan pengeringan jagung pipilan secara tradisional dengan bantuan sinar matahari. Namun, pengeringan tidak dapat dilakukan pada saat mendung/hujan. Selain itu tidak semua pedagang kecil memiliki tempat penyimpangan/gudang yang memenuhi syarat terutama sirkulasi udara yang baik sehingga jika jagung disimpan dalam waktu lama akan meningkatkan kelebaban (kadar air) dalam biji yang akan berdampak pada meningkatnya persentasi aflatoksin. Menurut Pleadin dkk. (2019), aflatoksin merupakan salah satu mikotoksin yang kemunculan dan perkembanganya dipicu oleh kerusakan mekanik pada biji, temperatur rendah, kelembaban dan kadar air yang relatif tinggi. Pada saat ini pedagang besar sudah menerapkan pengeringan dengan vertical dryer dan pengeringan menjadi standar prosedur dalam produksi jagung. Namun demikian, pananganan pasca panen

Tabel 4. Kualitas jagung di tingkat petani dan pedagang per provinsi (2017-2018)

\begin{tabular}{llcccccccc}
\hline & & \multicolumn{4}{c}{ Petani } \\
\cline { 3 - 9 } No & Provinsi & $\begin{array}{c}\text { Kadar air } \\
(\%)\end{array}$ & $\begin{array}{c}\text { Aflatoksin } \\
\text { B1 }(\mu \mathrm{g} / \mathrm{kg})\end{array}$ & $\begin{array}{c}\text { Biji } \\
\text { pecah } \\
(\%)\end{array}$ & $\begin{array}{c}\text { Biji rusak } \\
(\%)\end{array}$ & $\begin{array}{c}\text { Kadar air } \\
(\%)\end{array}$ & $\begin{array}{c}\text { Aflatoksin B1 } \\
(\mu \mathrm{g} / \mathrm{kg})\end{array}$ & $\begin{array}{c}\text { Biji pecah } \\
(\%)\end{array}$ & $\begin{array}{c}\text { Biji } \\
\text { rusak } \\
(\%)\end{array}$ \\
\hline 1 & NTT & $7,4 \pm 2,2$ & $13,3 \pm 16,6$ & $0,5 \pm 0,6$ & $0,50 \pm 0,7$ & $10,8 \pm 0,7$ & $28,8 \pm 48,9$ & $1,2 \pm 1,1$ & $4,6 \pm 2,8$ \\
2 & Jawa Tengah & $10,3 \pm 2,4$ & $42,5 \pm 126,2$ & $0,8 \pm 0,9$ & $0,9 \pm 1,0$ & $11,6 \pm 1,8$ & $133,2 \pm 254,5$ & $1,2 \pm 1,8$ & $1,1 \pm 0,7$ \\
3 & Jawa Barat & $20,4 \pm 5,7$ & $3,0 \pm 10,1$ & $1,9 \pm 5,6$ & $3,7 \pm 4,5$ & $18,1 \pm 6,5$ & $3,4 \pm 4,6$ & $0,78 \pm 0,8$ & $3,5 \pm 3,7$ \\
4 & Gorontalo & $8,4 \pm 1,2$ & $9,1 \pm 15,0$ & $0,6 \pm 0,4$ & $0,7 \pm 0,7$ & $8,6 \pm 1,5$ & $27,7 \pm 27,9$ & $0,5 \pm 0,3$ & $0,9 \pm 0,5$ \\
5 & Sumatera Utara & $12,9 \pm 6,1$ & $78,3 \pm 135,2$ & $1,7 \pm 2,8$ & $2,0 \pm 1,7$ & $18,8 \pm 11,1$ & $1,9 \pm 2,6$ & $7,0 \pm 12,7$ & $0,3 \pm 0,3$ \\
\hline
\end{tabular}




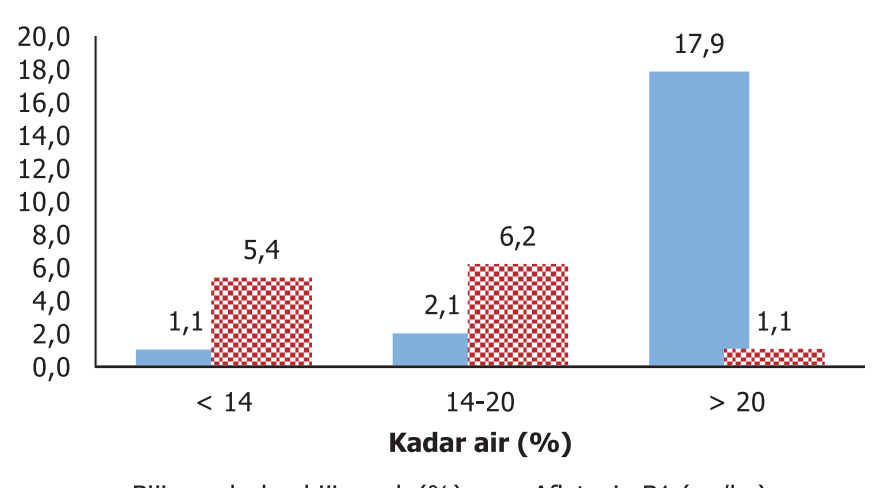

ఐ Biji pecah dan biji rusak (\%) : Aflatoxin B1 $(\mu \mathrm{g} / \mathrm{kg})$

(a)

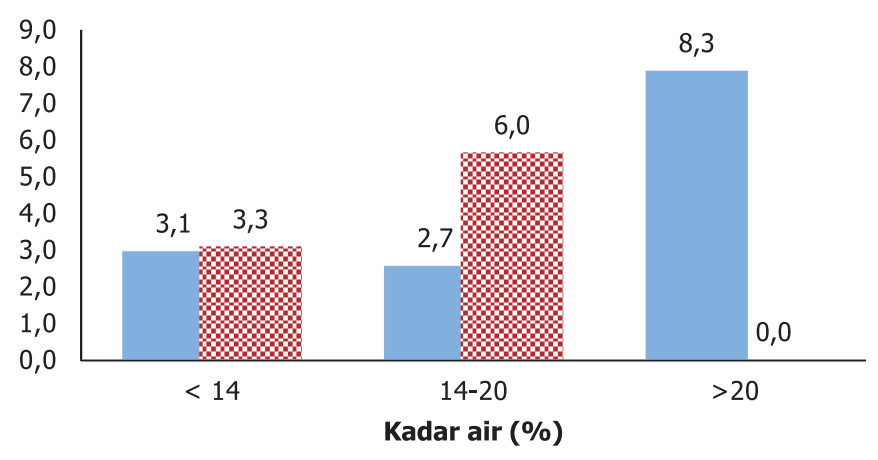

$\square$ Biji pecah dan biji rusak (\%) «Aflatoxin B1 $(\mu \mathrm{g} / \mathrm{kg})$

(b)

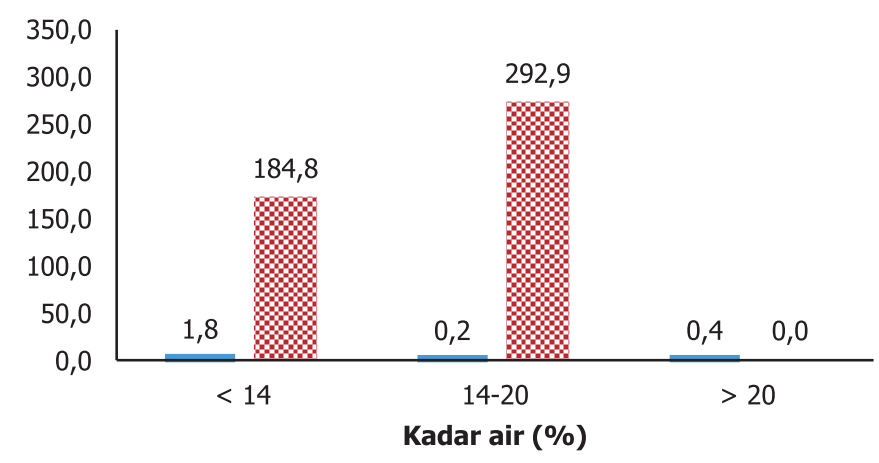

Biji pecah dan biji rusak (\%) \& Aflatoxin B1 $(\mu \mathrm{g} / \mathrm{kg})$

(c)

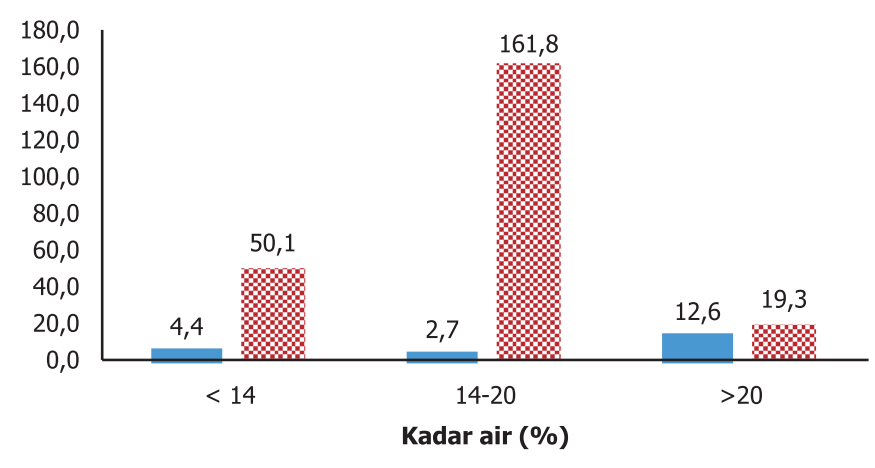

Biji pecah dan biji rusak (\%) \& Aflatoxin B1 $(\mu \mathrm{g} / \mathrm{kg})$

(d)

Gambar 1. Mutu jagung pipilan di beberapa provinsi: (a) Sumatera Utara; (b) Jawa Barat; (c) NTB; (d) Sulawesi Selatan

yang terlambat (dimulai pada saat tingkat pedagang besar) kurang memberikan dampak yang nyata jika dibandingkan perlakuan tersebut dikerjakan mulai ditingkat pedagang kecil.

Kadar air biji jagung di tingkat pedagang juga menunjukan tren yang meningkat. Hal ini disebabkan pedagang membeli jagung dari beberapa petani atau penjual dengan kadar air yang berbeda-beda. Pedagang yang tidak melakukan proses pengeringan akan menghasilkan jagung dengan kadar air yang bervariasi. Dalam memudahkan analisis, data yang diperoleh di beberapa provinsi dikelompokkan dalam beberapa kisaran kadar air yaitu $<14 \%, 14-20 \%$, dan $>20 \%$. Pengaruh kadar air terhadap biji pecah dan biji rusak serta kadar aflatoksin disajikan pada Gambar 1.

Gambar 1 menunjukan bahwa terdapat variasi persentase biji pecah dan rusak, serta kandungan aflatoxin pada berbagai kisaran pengelompokan kadar air. Hasil analisis korelasi menunjukan bahwa kadar air berkorelasi positif terhadap kemunculan aflatoxin pada biji jagung dibandingkan dengan faktor biji rusak, biji pecah serta biji pecah dan rusak (Tab 5). Kadar air dengan kisaran $14-20 \%$ memberikan kontribusi yang signifikan terhadap kadar aflatoxin pada biji jagung di sentra-sentra produksi Indonesia. Tampaknya kadar air dengan kisaran 14-20\% memberikan dukungan yang optimum bagi perkembangan jamur $A$. flavus dalam menghasilkan aflatoksin. Sebaliknya pada kadar air pada biji jagung di bawah $14 \%$ dan diatas 20\% kandungan aflatoksin menunjukkan kecenderungan yang menurun. A. flavus merupakan jamur penghasil mikotoksin berbahaya aflatoksin (Abrunhosa dkk., 2001) dengan kondisi optimum pertumbuhan untuk menghasilkan aflatoksin pada suhu $20-25^{\circ} \mathrm{C}$, RH $85 \%$, kadar air bahan $16 \%$ serta pH 6 (Safika, 2008).

Pengendalian aflatoksin dapat dilakukan dengan pengendalian kadar air jagung dalam simpanan, temperatur dan kondisi jagung, serta perlindungan mengggunakan pengawet kimia atau biologi (Bakoye dkk., 2017; Kamika dkk., 2016; Kamika dkk., 2014; Stasiewicz dkk., 2017; Milicevic dkk., 2015). 
Tabel 5. Korelasi kadar air, biji pecah, dan biji rusak terhadap kandungan aflatoksin

\begin{tabular}{|c|c|c|c|c|c|}
\hline Variabel & Variabel & Korelasi Pearson & P-value & $\mathrm{F}$ & F crit \\
\hline \multirow{4}{*}{ Kadar air } & $<14 \%$ & 0,14 & $0,014 *$ & 4,56 & 3,12 \\
\hline & $14 \%-20 \%$ & 0,19 & & & \\
\hline & $>20 \%$ & $-0,99$ & & & \\
\hline & Keseluruhan & 0,14 & & & \\
\hline \multirow{4}{*}{ Biji pecah } & $<1 \%$ & $-0,09$ & 0,379 & 0,98 & 3,12 \\
\hline & $1 \%-4 \%$ & $-0,28$ & & & \\
\hline & $>4 \%$ & $-0,43$ & & & \\
\hline & Keseluruhan & $-0,09$ & & & \\
\hline \multirow{4}{*}{ Biji rusak } & $<2 \%$ & $-0,08$ & 0,448 & 0,81 & 3,12 \\
\hline & $2 \%-8 \%$ & 0,07 & & & \\
\hline & $>8 \%$ & $-0,38$ & & & \\
\hline & Keseluruhan & $-0,15$ & & & \\
\hline \multirow{4}{*}{$\begin{array}{l}\text { Biji pecah dan } \\
\text { biji rusak }\end{array}$} & $<2 \%$ & $-0,27$ & 0,525 & 0,65 & 3,13 \\
\hline & $2 \%-8 \%$ & $-0,11$ & & & \\
\hline & $>8 \%$ & $-0,48$ & & & \\
\hline & Keseluruhan & $-0,14$ & & & \\
\hline
\end{tabular}

*Signifikan pada tingkat kepercayaan 95\%

Persentase biji pecah dan rusak cenderung meningkat dengan bertambahnya kadar air pada biji jagung (Gambar 1). Biji pecah dan rusak dapat terjadi pada proses pascapanen, pengangkutan, dan pemasaran. Hal ini sesuai dengan hasil penelitian Munkvold dkk. (2019) yang menyatakan bahwa selama panen dan transportasi, biji dapat mengalami kerusakan fisik, dan kerusakan ini berkontribusi terhadap perkembangan jamur dan mikotoksin.

Fasilitasi sarana pascapanen belum mampu menstabilkan kualitas jagung hasil produksi. Namun, mesin pertanian dibutuhkan untuk mengatasi kelangkaan tenaga kerja berkeahlian, kekurangan tenaga kerja manusia dan hewan, serta kecenderungan upah tenaga kerja yang terus meningkat. Pengembangan pertanian tidak dapat dipisahkan dari teknologi mekanisasi (Sims and Kienzle, 2017), karena. produksi secara manual dan tradisional tidak dapat mendukung peningkatan suplai (Rugumamu dkk., 2011). Namun demikian, penggunaan tenaga terampil dalam pengoperasian alat mesin pertanian tersebut masih perlu untuk dioptimalkan agar kualitas biji jagung yang dihasilkan juga meningkat.

Petani yang menjaga mutu jagung tidak mendapatkan tambahan pendapatan yang signifikan. Harga jual jagung dengan kadar air di bawah $17 \%$ hampir sama dengan harga jual jagung dengan kadar air $17-20 \%$. Meskipun di beberapa daerah terjadi perbedaan harga jual jagung tersebut, namun perbedaan tersebut tidak mampu menutupi biaya operasional pengeringan. Penundaan penjualan jagung karena proses pengeringan juga dapat merugikan petani karena kebutuhan uang cash segera untuk biaya operasional produksi berikutnya. Aktifitas perontokan tidak memperhatikan kadar air jagung tongkolan. Petani hanya mengukur kesiapan jagung tongkolan untuk dipipil berdasarkan kekerasan kulit permukaan jagung dan penjemuran jagung tongkolan hampir tidak pernah dilakukan. Pedagang membeli jagung pipilan tanpa mempertimbangkan butir pecah atau rusak. Kerusakan butir tersebut dapat muncul akibat aktifitas perontokan jagung tongkolan dengan kadar air yang tinggi. Penyimpanan dan penundaan penjualan jagung pipilan yang mengalami kerusakan butir dapat memicu pertumbuhan aflatoksin. Kerusakan butir, kadar air tinggi dan tidak seragam, ditambah lagi lokasi penyimpanan sementara yang lembab, merupakan faktor utama tingginya aflatoksin pada jagung.

\section{KESIMPULAN}

Dampak fasilitasi sarana pascapanen terhadap peningkatan mutu jagung belum menunjukkan hasil yang signifikan. Sarana pascapanen tersebut belum dimanfaatkan secara optimal karena tidak adanya insentif bagi petani yang menjaga mutu jagung. Aktivitas setelah perontokan tidak memberikan tambahan 
pendapatan bagi mereka. Sementara, petani tidak bisa menunda penjualan jagung pipilan mereka karena petani dihadapkan akan kebutuhan pokok mendasar. Dukungan modal dan pelatihan pemanfaatan mesin pascapanen sangat dibutuhkan oleh petani dalam mendukung peningkatan mutu jagung. Advokasi pembelian jagung petani berbasis kualitas perlu untuk digalakkan dan mendapat dukungan dari pemerintah.

\section{KONFLIK KEPENTINGAN}

Tidak ada konflik kepentingan dalam penelitian ini.

\section{DAFTAR PUSTAKA}

Abass, A. B., Ndunguru, G., Mamiro, P., Alenkhe, B., Mlingi, N., \& Bekunda, M. (2014). Post-harvest food losses in a maize-based farming system of semi-arid savannah area of Tanzania. Journal of Stored Products Research, 57, 49-57. https://doi.org/10.1016/j.jspr.2013.12.004

Abrunhosa, L., Paterson, R. R. M., Kozakiewicz, Z., Lima, N., \& Venâncio, A. (2001). Mycotoxin production from fungi isolated from grapes. Letters in Applied Microbiology, 32(4),240-242.https://doi.org/10.1046/j.1472765X.2001.00897.x

Bakoye, O. N., Baoua, I. B., Seyni, H., Amadou, L., Murdock, L. L., \& Baributsa, D. (2017). Quality of maize for sale in markets in Benin and Niger. Journal of Stored Products Research, 71, 99-105. https://doi.org/10.1016/j. jspr.2017.02.001

[BPS] Badan Pusat Statistik. (2019). Statistical Yearbook of Indonesia.

[BSN] Badan Standarisasi Nasional (ID). (2013). SNI 3920:2013, Jagung.

[BSN] Badan Standarisasi Nasional (ID). (2013). SNI 4483:2013, Jagung-Bahan Pakan Ternak.

Djuric, I., \& Götz, L. (2016). Export restrictions - Do consumers really benefit? The wheat-to-bread supply chain in Serbia. Food Policy, 63, 112-123. https://doi. org/10.1016/j.foodpol.2016.07.002

Gu, Ri-liang., Huang, Ran., Jia, Guang-yao., Yuan, Zhi-peng., Ren, Li-sha, Li LI, \& Wang, Jian-hua. (2019). Effect of mechanical threshing on damage and vigor of maize seed threshed at different moisture contents. Journal of Integrative Agriculture, 18(7), 1571-1578. https://doi. org/10.1016/S2095-3119(18)62026-X

Kamika, I., Ngbolua, K. te N., \& Tekere, M. (2016). Occurrence of aflatoxin contamination in maize throughout the supply chain in the Democratic Republic of Congo. Food Control, 69(March 2018), 292-296. https://doi. org/10.1016/j.foodcont.2016.05.014
Kamika, I., Mngqawa, P., Rheeder, J. P., Teffo, S. L., \& Katerere, D. R. (2014). Mycological and aflatoxin contamination of peanuts sold at markets in Kinshasa, Democratic Republic of Congo, and Pretoria, South Africa. Food Additives and Contaminants: Part B Surveillance, 7(2), 120-126. https://doi.org/10.1080/19393210.2013.858 187

Krout-Greenberg, N. D., Puschner, B., Davidson, M. G., \& DePeters, E. J. (2013). Preliminary study to assess mycotoxin concentrations in whole corn in the California feed supply. Journal of Dairy Science, 96(4), 2705-2712. https://doi.org/10.3168/jds.2012-5957

Maiyar, L. M., \& Thakkar, J. J. (2017). A combined tactical and operational deterministic food grain transportation model: Particle swarm based optimization approach. In Computers and Industrial Engineering (Vol. 110). Elsevier Ltd. https://doi.org/10.1016/j.cie.2017.05.023

Milicevic, D., Nesic, K., \& Jaksic, S. (2015). Mycotoxin Contamination of the Food Supply Chain - Implications for One Health Programme. Procedia Food Science, 5, 187-190. https://doi.org/10.1016/j.profoo.2015.09.053

Mitchell, D., Parra, R., Aldred, D., Magan, N., (2004). Water and temperature relations of growth and ochratoxin A production by Aspergillus carbonarius strains from grapes in Europe and Israel. J. Appl. Microbiol. 97, 439445.

Munkvold, G. P., Arias, S., Taschl, I., \& Gruber-Dorninger, C. (2018). Mycotoxins in corn: Occurrence, impacts, and management. Corn: Chemistry and Technology, 3rd Edition (3rd ed.). Elsevier Inc. https://doi.org/10.1016/ B978-0-12-811971-6.00009-7

Pandey, P., Bajrachrya, J., \& Pokharel, S. (2013). Influence of corn (Zea mays $L$ ) seed processing with a locally produced sheller on seed quality and their damage. International Journal of Applied Sciences and Biotechnology, 1(2), 67-70. https://doi.org/10.3126/ijasbt.v1i2.8198

Panison, F., Sangoi, L., Kolling, D. F., Coelho, C. M. M., \& Durli, M. M. (2016). Harvest Time and Agronomic Performance of Maize Hybrids with Contrasting Growth Cycles. Acta Scientiarum - Agronomy, 38(2), 219-226. https://doi. org/10.4025/actasciagron.v38i2.27901

Parfitt, J., Barthel, M., \& MacNaughton, S. (2010). Food waste within food supply chains: Quantification and potential for change to 2050. Philosophical Transactions of the Royal Society B: Biological Sciences, 365(1554), 30653081. https://doi.org/10.1098/rstb.2010.0126

Pleadin, J., Frece, J., \& Markov, K. (2019). Mycotoxins in food and feed. Advances in Food and Nutrition Research (1st ed., Vol. 89). Elsevier Inc. https://doi.org/10.1016/ bs.afnr.2019.02.007

Purwadaria, H.K. (1988). Buku Pegangan: Teknologi Penanganan Pascapanen Jagung. Edisi Kedua. Deptan, 
FAO, UNDP. Development and Utilization of Postharvest Tools and Equipment, INS/088/077.

Rugumamu, C. P., Muruke, M. H. S., Hosea, K. M., \& Ismail, F. A. R. (2011). Advances in insect pest management technologies of agricultural crops: an integrated approach. 55-61.

Sims, B., \& Kienzle, J. (2017). Sustainable agricultural mechanization for smallholders: What is it and how can we implement it? Agriculture (Switzerland), 7(6), 1-21. https://doi.org/10.3390/agriculture7060050

Safika. (2008). Korelasi Aspergillus flavus dengan konsentrasi aflatoxin $\mathrm{B}_{1}$ pada ikan kayu. J. Ked. Hewan, 2(September 2008), 170-175.

Stasiewicz, M. J., Falade, T. D. O., Mutuma, M., Mutiga, S. K., Harvey, J. J. W., Fox, G., Pearson, T. C., Muthomi, J. W., \& Nelson, R. J. (2017). Multi-spectral kernel sorting to reduce aflatoxins and fumonisins in Kenyan maize. Food Control, 78, 203-214. https://doi.org/10.1016/j. foodcont.2017.02.038

Stewart, W. M., \& Roberts, T. L. (2012). Food security and the role of fertilizer in supporting it. Procedia Engineering, 46, 76-82. https://doi.org/10.1016/j.proeng.2012.09.448

Subekti, E. (2010). Ketahanan Pakan Ternak Indonesia. Jurnal Ilmu-IImu Pertanian, 5(2), 63-71.
Udomkun, P., Wossen, T., Nabahungu, N. L., Mutegi, C., Vanlauwe, B., \& Bandyopadhyay, R. (2018). Incidence and farmers' knowledge of aflatoxin contamination and control in Eastern Democratic Republic of Congo. Food Science and Nutrition, 6(6), 1607-1620. https://doi. org/10.1002/fsn3.735

Udomkun, P., Wiredu, A. N., Nagle, M., Müller, J., Vanlauwe, B., \& Bandyopadhyay, R. (2017). Innovative technologies to manage aflatoxins in foods and feeds and the profitability of application - A review. Food Control, 76, 127-138. https://doi.org/10.1016/j.foodcont.2017.01.008

Van Egmond, H. P., Schothorst, R. C., \& Jonker, M. A. (2007). Regulations relating to mycotoxins in food: PPPPerspectives in a global and European context. Analytical and Bioanalytical Chemistry, 389(1), 147-157. https://doi.org/10.1007/s00216-007-1317-9

Wild, C. P., \& Gong, Y. Y. (2009). Mycotoxins and human disease: A largely ignored global health issue. Carcinogenesis, 31(1), 71-82. https://doi.org/10.1093/ carcin/bgp264

Zulkifli, N. A., \& Zakaria, L. (2017). Morphological and Molecular diversity of aspergillus from corn grain used as livestock feed. HAYATI Journal of Biosciences, 24(1), 26-34. https://doi.org/10.1016/j.hjb.2017.05.002 